\title{
A kinetic study of a membrane anaerobic reactor (MAR) for treatment of sewage sludge
}

\begin{abstract}
The application of kinetic models (Monod, Contois and Chen \& Hashimoto) and overall microbial kinetic on the membrane anaerobic reactor (MAR) for treatment of sewage sludge was investigated. The system consists of a cross-flow ultrafiltration membrane and six steady states were attained over a range of mixed liquor suspended solids of 12,760-21,800 mg/l. The results of all six steady states were successfully fitted above $98 \%$ for three known kinetics. The growth yield coefficient, Y, was found to be $0.74 \mathrm{gVSS} / \mathrm{gCOD}$ while the specific microorganism decay rate was $0.20 \mathrm{~d}-1$. The $\mathrm{k}$ values were in the range of 0.350 $0.519 \mathrm{gCOD} / \mathrm{gVSS}$.d and $\mu \mathrm{max}$ values were between 0.259 and $0.384 \mathrm{~d}-1$. The COD removal efficiency was $96.5-99 \%$ with HRT of 7.8 days. The methane gas yield was between $0.19 \mathrm{l} / \mathrm{g}$ $\mathrm{COD} / \mathrm{d}$ to $0.54 \mathrm{l} / \mathrm{g} \mathrm{COD} / \mathrm{d}$ when the organic loading rate increased from $0.1 \mathrm{~kg} \mathrm{COD} / \mathrm{m} 3 / \mathrm{d}$ to $10 \mathrm{~kg} \mathrm{COD} / \mathrm{m} 3 / \mathrm{d}$. The system efficiency was greatly influenced by SRT and OLRs. Membrane flux rate deterioration was observed from $62.1 \mathrm{l} / \mathrm{m} 2 / \mathrm{h}$ to $6.9 \mathrm{l} / \mathrm{m} 2 / \mathrm{h}$ due to membrane fouling. (C) 2005 Elsevier B.V. All rights reserved.
\end{abstract}

Keyword: Anaerobic; Kinetics; Membrane; Sewage sludge; Ultrafiltration 